\title{
Introducing the New School of Convict Criminology ${ }^{1}$ Stephen C. Richards and Jeffrey lan Ross
}

That's the reality, and to hell with what the class-room bred, degree toting, grant-hustling 'experts' say from their well-funded, airconditioned offices far removed from the grubby realities of the prisoner's lives. (Rideau and Wikberg, 1992: 59)

\section{INTRODUCTION}

The United States imprisons more people than any other country in the Western world. Meanwhile, prison research is dominated by government funding and conducted by academics or consultants, many of them former employees of the law enforcement establishment (ex-police, correctional, probation, or parole officers) who subscribe to conservative ideologies and have little empathy for prisoners. Much of this "managerial research" routinely disregards the harm perpetrated by criminal justice processing of individuals arrested, charged, and convicted of crimes (Clear, 1994; Cullen, 1995).

If legislators, practitioners, researchers, and scholars are serious about addressing the corrections crisis (e.g., Clear, 1994; Welch, 1996, 1999; Austin and Irwin, 2001), we need to be more honest and creative with respect to the research we conduct, and the policies we advocate, implement, and evaluate. In an effort to promote this objective, this article introduces what we are calling "Convict Criminology," and reviews the theoretical and historical grounding, current initiatives, and dominant themes of this emerging school and social movement.

\section{THEORETICAL AND HISTORICAL GROUNDING}

In order to appreciate the context of Convict Criminology, it is necessary to understand the steps taken to arrive at this juncture. Four interrelated

1 Acknowledgments: We wish to thank William G. Archambeault, Bruce Arrigo, James Austin, Vicky Beck, Eric Cadora, Todd Clear, Susan Dearing, Preston Elrod, Eddie Ellis, Jeff Ferrell, Bob Gaucher, Gil Geis, Marianne-Fisher Giorlando, Warren Gregory, Victor Hassine, Richard G. Hogan, John Irwin, Richard S. Jones, Charles S. Lanier, Alan Mobley, Daniel S. Murphy, Greg Newbold, Barbara Owen, Jon Marc Taylor, Chuck Terry, Jim Thomas, Susan Tucker, Edward Tromanhauser, William S. Tregea, Ron Simons, and Michael Welch, for their contributions to and support of Convict Criminology. 
movements, factors, and methodologies led to the birth of Convict Criminology: theoretical developments in criminology, the failure of prisons, the authenticity of insider perspectives, and the centrality of ethnography.

\section{Theoretical Developments in Criminology}

The history of criminological theory consists of a series of reform movements (Vold and Bernard, 1996). As early as the 1920s, biologicallybased arguments of criminal causation were being replaced by environmental, social-economic, and behavioral explanations. Even in the field of radical and critical criminology there have been a series of divisions (Lynch, 1996; Ross, 1998). Since the 1970 s, critical criminology has splintered into complementary perspectives including feminism (e.g., Chesney-Lind, 1991; Daly, 1994; Owen, 1998), postmodernism (e.g., Arrigo 1998a, 1998b; Ferrell, 1998), left realism (e.g., Young and Matthews, 1992), peacemaking (e.g., Pepinsky and Quinney, 1991; Quinney, 1998), and cultural criminology (e.g., Ferrell and Sanders, 1995; Ferrell, 1996). This multiplicity of perspectives suggests that radical and critical criminology has broadened its intellectual endeavor. While these diverse discourses and "metanarratives ... open up some new conceptual and political space" (Ferrell, 1998: 64), they too often remain the intellectual products of the well-meaning yet privileged, with only minimal reference and relevance to the victims of the criminal justice machine. Perhaps in the new millennium criminologists and other social scientists might also realize that convict voices, in many instances, have been forgotten, marginalized, or simply ignored (Gaucher, 1998).

\section{The Failure of Prisons}

Many prominent criminologists have discussed the failure of prisons to correct criminal behavior, and the differential effects of incarceration are well known. According to Sutherland et al. (1992: 524), "[s]ome prisoners apparently become 'reformed' or 'rehabilitated,' while others become 'confirmed' or 'hardened' criminals. For still others, prison life has no discernible effect on subsequent criminality or noncriminality." Johnson (1996: xi) suggested that, "[p]risoners serve hard time, as they are meant to, but typically learn little of value during their stint behind bars. They adapt to prison in immature and often destructive ways. As a result they leave prison no better, and sometimes considerably worse, then when they went in." Similarly, Reiman (1995: 2) 
argued that the correctional system was designed to "maintain and encourage the existence of a stable and visible "class' of criminals."

Needless to say, we should not assume all prisoners are criminals, or that committing crime has anything to do with going to prison the first time-and even less the second or third. Considering the dramatic growth in prison populations (Austin and Irwin, 2001: 1-16; Richards, 1998: 125-126), the numbers of "innocent" victims will also continue to grow. The first failure of correctional institutions is that they incarcerate hundreds of thousands of prisoners who, while they were convicted of a crime, are not violent and pose little, if any, threat to the community. The second is that they hold people too long; as Austin and Irwin (2001: 143-146) demonstrated, it is about time, not just "hard time" (Johnson, 1996), but "long time" and "repeated time" in prison. The third tragedy of prisons is "they don't do more to rehabilitate those confined in them" (Rideau, 1994: 80). Instead, prison systems are transformed into vast depositories for drug offenders, minorities, and petty offenders (Miller, 1996: 10-47; Austin and Irwin, 2001: 17-62). One cursory look at the gun towers, walls, and razor wire is evidence that prisons were built to warehouse and punish and not to rehabilitate.

\section{Inside Perspective}

The existing literature that provides an "inside perspective" on crime and convicts can be divided into six groups. The first group is edited anthologies by prison reform activists (e.g., Rosenblatt, 1996; Burton-Rose, with Pens and Wright, 1998). Embedded in these works are chapters or short pieces written by political activists, lawyers, journalists, and prisoners. The second collection of writing is journalists' accounts of life inside prison (e.g., Mitford, 1973; Wicker, 1975; Earley, 1993; Bergner, 1999; Conover, 2000). Third, prison journalism written by convicts in prison newspapers, for example The Angolite, or appearing in free-world publications like the Journal of Prisoners on Prisons. The fourth group includes edited collections of authentic convict writing (e.g., Martin, 1995; Franklin, 1998; Morris, 1998; Johnson and Toch, 1999; Leder, 1999; Chevigny, 2000). The fifth collection is sole-authored books or edited works by academics that may employ observation and/or interviews of criminal offenders or convicts (e.g., Schultz, 1991; Churchill and Vanderwall, 1992; Johnson, 1996; Cromwell, 1996; Walens, 1997, May, 2000). The last, and most prominent category, is composed of monographs written by convicts about life in prison (e.g., Jenet, 1949a, 1949b; Chessman, 1954, 1955, 1957; 
Cleaver, 1968; Jackson, 1970, 1972; Abbott, 1981; Rideau and Wikberg, 1992; Abu-Jamal, 1995; Hassine, 1996; Peltier, 1999).

The first four groups, be they convicts, activists, journalists, or academic editors, write "stories" or investigative reports rarely connecting their discussion to the debates found in the scholarly literature. The fifth collection of authors are academics, who while they support their research with excerpts from prisoner interviews, and may themselves at one time have been employed inside prisons, are still writing from a privileged perspective, as compared to the lived experience of convicts. The last group writes authentic and compelling accounts of prison life, but are generally unable to ground their discussion in academic research (e.g., Gaucher, 1999). Missing, or underutilized, are the research accounts by academics who themselves have served prison time.

\section{Centrality of Ethnography}

Convict Criminology is also the logical result of criminologists (e.g., Newbold, 1982/1985, 1987; Richards, 1995; Ferrell, 1993; Ferrell and Hamm, 1998) using ethnographic methods in order to better understand their subject matter. Clearly, the use of ethnographic methods is not new in the field of penology or corrections (e.g., Sutherland, 1937; Sykes 1956, 1958; Sykes and Messinger, 1960; Jacobs, 1977; Peak, 1985; Lombardo, 1989; Farkas, 1992). For example, during the 1930s, Clemmer (1940/1958), while employed as a sociologist on the prison mental health staff of Menard Penitentiary (Illinois), collected extensive information on the convict social system.

Ex-convict academics have also carried out a number of significant ethnographic studies. In a series of articles and monographs (Irwin and Cressey 1962; Irwin, 1970, 1980, 1985; Austin and Irwin, 2001), Irwin, who served prison time in California, drew upon his experience as a convict to interview prisoners, and analyze jail admissions and subtle processes in prison. McCleary (1978/1992), who did both state and federal time, wrote his classic "sociology of parole" through participant observation of parole officers at work and on the street. Terry (1997), a former California and Oregon state convict, wrote about how prisoners used humor to mitigate the managerial domination of penitentiary authorities. Newbold (1982/1985, 1987, 2000), having served prison time in New Zealand, used both qualitative and quantitative methods to analyze crime and corrections in his country. Finally, Richards and Jones (1997), both former prisoners, used "inside experience" to inform their observations, interviewing Iowa convicts upon their transfer to community work release 
centers. Each of these studies benefited from the inside experience of the investigators.

These movements, factors, and methodologies suggest that while academic criminology has flourished intellectually, and has made serious efforts to extend theoretical ideas, there remains a disjuncture, and serious distance, between the critical empirical literature and the real world of convicts. Our remoteness from our subject might be considered as a crisis best remedied by utilizing the emerging research we are introducing as Convict Criminology.

\section{CURRENT INITIATIVES}

Having outlined the factors contributing towards the formation of the New School of Convict Criminology, we are in a better position to consider the initiatives that our collective effort has taken to date. The subjects covered include: defining the New School of Convict Criminology, inclusion criteria, understanding who these people are, the pre-eminence of John Irwin, its objectives and issues, and the questions asked and answered.

\section{Defining the New School of Convict Criminology ${ }^{2}$}

Convict Criminology is primarily essays and empirical research written by convicts or ex-convicts in possession of a $\mathrm{Ph}$.D., or on their way to completing one, and by enlightened academics who critique existing literature, policies, and practices, and contribute a new perspective on criminology, criminal justice, corrections, and community corrections. This is a "new criminology" (Taylor, Walton, and Young, 1973) led by ex-convicts who are now academic faculty. These men and women, who have worn both prison uniforms and academic regalia, served years behind prisons walls. Now, as academics, they are the primary architects of the movement. The convict scholars are able to do what

2 Our use of "new" is mirrored on Talyor, Walton, and Young's (1973) seminal work The New Criminology. This monograph generated considerable controversy and intellectual debate in our discipline. These authors were critical of positivist, functionalist, and labeling approaches that failed to consider how the criminal law, policing, and corrections were socio-political constructions of class domination and the logical priorities of capitalism. Our use of "school" is similar to the Frankfurt School and the New School of Social Research, which suggests a collective effort grounded in a creative and critical research tradition. 
most previous writers could not: merge their past with their present and provide a provocative approach to the academic study of criminology, criminal justice, and corrections. These authors, as a collective, are the future of a realistic paradigm that promises to challenge the conventional research findings of the past.

The ex-convict professors have endured years of lockup in penitentiaries and correctional institutions; lived in crowded, noisy, violent cellblocks; and emerged to complete graduate degrees and become professors of sociology, criminology, criminal justice, and related disciplines. They have an intimate knowledge of "penal harm" (Clear, 1994)_and in some cases wear as scars and tattoos upon their skin. They are like Steinbeck's character Tom Joad (portrayed by Henry Fonda in the movie) in The Grapes of Wrath: people with something to say, an anger that will not betray them. They do not write for vitae lines, promotions, or tenure. They write so that one day the ghosts will sleep.

Together, ex-convict graduate students and professors are now working together to build their expertise in both subject and methodology. We now number over a dozen ex-con professors of sociology, criminology, and criminal justice from Anglo-American democracies. To this we add a growing number of ex-convict graduate students that are joining us as they complete their dissertations, and established criminologists without criminal records who are well known for their critical orientation towards managerial criminology, criminal justice, and corrections. The dramatic expansion in arrests, convictions, and the rate of incarceration guarantees that the number of professors with profound and traumatic first-hand experience with the criminal justice system will continue to increase. In addition, some of the most important members of our growing group are prominent critical criminologists who, while not ex-cons, have contributed to both the content and context of our new school. This growing pool of talent, with its remarkable insight and resources, is the foundation of our effort.

\section{Who Are These People?}

The convict authors can be described, in terms of academic experience, as three distinct cohorts. The first are the more senior members, full and associate professors, some with distinguished research records. A second group consists of assistant professors just beginning to contribute to the field. The third, only some of whom have been identified, are the graduate student ex-convicts. 
Regardless of academic status, we can understand the ex-convicts as two distinct but overlapping groups with different personal dispositions towards our collective. The first group embraced the "new school" with little, if any, hesitation. Some of these members are known ex-con academics. The second group are ex-con professors and graduate students who share our correspondence and confidence, and provide those of us who are "out" with support and encouragement, but for a number of personal and professional reasons, have elected to remain anonymous - "in the closet"- where only their trusted friends know of their past. Some of their personal reasons include their reluctance to revisit a painful time in life, and a wish to put the past behind. Professionally, a number of the convict professors have expressed concerns that by appearing in print they might be denied fair access to government research grants. A few of the graduate students are concerned about "coming out" while still in graduate school and before they test the job market.

While the ex-cons provide Convict Criminology with unique and original experiential resources, some of the most important contributors may yet prove to be scholars, who while having never served prison time, may have or will, at some time in the future, be arrested, charged and/or convicted of crimes. This situation may lead them to be reasonably empathetic. The inclusion of non ex-cons in the new school's original cohort provides the means to extend the influence of the new school while also supporting existing critical criminology perspectives.

The school's mission and purpose emerged as writers shared their prison and academia experiences. Together, these academic authors critique existing theory and present new research from a convict or insider perspective. In short, they "tell it like it is." In doing so, they hope to illuminate the message that "it's about time" (Austin and Irwin, 2001): time served, time lost, and time that taught shared lessons. In demarcating the field of study for this new school, the contributors recognize that they are not the first to criticize the prison and correctional practices. They pay their respects to those who have already raised critical questions about prisons and suggested realistic humane reforms. However, Clear identified the problem in his foreword to McCleary's (1992: ix) Dangerous Men: "Why does it seem that all good efforts to build reform systems seem inevitably to disadvantage the offender?" The answer is that, despite the best intentions, reform systems were never intended to help convicts. The real problem is that the reformers rarely even bothered to ask 
the convicts what reforms they desired. The new school corrects this oversight, as the faculty are educated "con-sultants" (Mitford, 1973: 15).

\section{The Pre-eminence of John Irwin}

The most prominent ex-convict criminologist is John Irwin. His work and professional conduct over the years has inspired the group. In 1997, in San Diego, we had our first panel (organized by Chuck Terry) at an ASC annual meeting. That evening, over dinner, Irwin, along with Jim Austin, Stephen Richards, and Chuck Terry, discussed the potential of Convict Criminology. Irwin (Irwin and Cressey, 1962; Irwin 1970, 1980, 1985; Austin and Irwin, 2001) recalled how he had always wanted to assemble a group of ex-con scholars to write criminology from a convict perspective. The problem was, over the last forty years, there has only been a few ex-convicts that held academic positions. Ironically, the drug war, and the dramatic increase in prison populations over the last two decades, has added to our numbers and provided the opportunity to assemble this group.

Irwin has mentored and supported the group from the beginning. We have held long informal meetings at ASC and ACJS conferences, with Irwin generously spending time getting to know each member of the group. Irwin's counsel has been to declare honestly who we are, what we experienced and observed, and to do ethnography that tells the truth (Ferrell and Hamm, 1998; Miller and Tewksbury, 2000).

\section{Its Objective}

Convict Criminology challenges managerial criminology, criminal justice, and corrections. Research and publication by this group (e.g., Richards, 1990, 1995, 1998; Richards and Jones, 1997; Terry, 1997; Newbold, 2000; Austin and Irwin, 2001) should be viewed as a dramatic attempt to critique, update, and improve the critical literature in the field. We have two goals. First, to transform the way research on prisons is conducted. Second, to insist that our professional associations (e.g., ASC, ACJS) begin to articulate policy reforms that make the criminal justice system humane.

\section{Issue-Based}

Convict Criminology is issue-based and not necessarily structured by the traditional disciplinary divisions assumed by criminology, criminal justice, or corrections. These subjects generally provide description of the etiology of 
crime, stages of the criminal justice system, and correctional control as separate entities. Unfortunately, too often this approach has resulted in piecemeal research and analysis conducted by armchair technicians and theorists, with precious little practical understanding of crime, criminals, and corrections.

Most academic criminologists fail to penetrate and comprehend the lived experience of defendants and prisoners, or are simply misinformed. In comparison, Convict Criminology is research carried out by our "felonious friends" who have both personal and abstract knowledge of the criminal justice machinery.

\section{Questions Asked and Answered}

A series of questions are answered by writers doing research in this area. What is wrong with criminology, criminal justice, and corrections literature? What is missing from the literature and discipline? How do the views of excon academics differ from those without insider status? What is it like for exprisoners to read academic material about crime, criminals, and corrections? What did the writers learn about the criminal justice system from being processed through arrest, court, jail, prison, and release? What unique research methods did the convict authors employ in their research? Why do authors need to be honest and truthful about themselves as they approach their research and writing? Did prisoners' views on crime and corrections change when they became scholars? What obstacles did these ex-cons experience as university employees? As ex-convict professors, how are they perceived by colleagues? What suggestions do former prisoners have for the reform of criminology, criminal justice, and prisons?

\section{Development and Support of Critical Criminological Perspectives}

As the field of criminology matures it incorporates new voices, ostensibly refutes established hypotheses and theories, and develops new ones. Critical criminology contributes many of the most innovative theoretical developments. It is our hope that the New School of Convict Criminology will support critical criminologists to "ground" their theory in ethnographic accounts. This, in turn, will inform specific policy recommendations that will encourage academics, policy makers, and correctional administrators.

As the prison population continues to grow, so too will the number of individuals released back to the community. Many of these persons, as they 
re-enter conventional society, will attend universities and study criminology, criminal justice, and corrections.

As this process continues, some of these former prisoners will complete their graduate educations and become the future cohorts of the new school. We predict that, over time, this New School of Convict Criminology will provide the public with a more realistic understanding of crime, criminal justice, and corrections that is based on experience and cutting-edge research.

\section{Paying Our Respects to the Convict Authors Still in Prison}

A number of the Convict Criminologists continue friendships and working relationships with writers in penitentiaries, some of whom are well published in criminology (e.g., Victor Hassine, Wilbert Rideau, Jon Marc Taylor). We all owe a debt of gratitude to the many men and women who live inside prison, and continue to write and publish their ideas, thoughts, and observations. Exconvict academics use correspondence, phone calls, and prison visits with these individuals to stay current with the conditions inside correctional facilities.

Contributors to this project pay their respects to the prisoners that have and are attempting to write serious commentaries on prison life (e.g., Abbott, 1981; Rideau and Wikberg, 1992; Abu-Jamal, 1995, 2000; Taylor, 1995; Hassine, 1996; Peltier, 1999). We recognize that much of their research and writing, while critically informed, based on their experiences inside prisons, may only be partially grounded in the academic literature. After all, many of these authors lack or have difficulties obtaining the typical amenities that most scholars take for granted (e.g., a computer for writing, university library, and colleagues educated in criminology who might provide feedback on their work). They struggle to write by hand, or with broken and worn out machines, and without supplies (e.g., typewriter ribbons, paper, envelopes, stamps, etc.). In addition, their phones calls are monitored and recorded, and all their mail sent or received is opened, searched, and read by prison authorities. In many cases, they suffer the retribution of prison authorities, including denial of parole, loss of good-time credit, physical threats from staff or inmates, frequent cell searches, confiscation of manuscripts, trips to "the hole," and disciplinary transfers to other prisons.

The convict criminologists, both the ex-cons and non-cons, have it easier. They have benefited from superior resources in order to open the window on a subterranean world of confinement that few people know. 


\section{Reforming the Study of Criminology and Criminal Justice}

The notion of reform is nothing new in the academic disciplines of criminology and criminal justice. One might even argue that the entire field was originally conceived in an effort to provide civilized legal solutions to socio-economic conflicts. However, we are shocked by the number of criminologists, who while they claim to be experts, have little or no first-hand experience with prisoners. The result is criminology and criminal justice writing which is dominated by academic technicians that manipulate data sets and publish statistical trivia from the safety of their offices. Unfortunately, much of this number crunching, which masquerades as objective science, only obscures the truth and supports the functions of managerial elites. The analytical interpretation of aggregate data does not replace the need to go to the streets, visit penal institutions, and observe and interview the victims of the criminal justice juggernaut (Gordon, 1990).

We have argued for the primacy of ethnographic methods, or for those which involve speaking, observing, or interacting with prisoners. This methodology requires researchers to take some chances, to get a little "dirty," as they sample reality, and even, although this may be considered an "academic felony" or "scholar's sin," to get emotionally involved with their subject. Objectivity is an illusion that illustrates the class privilege and social distance of the armchair technician from the sordid lives of criminals and convicts. In contrast, the prison ethnographer, by entering prisons and spending time with convicts, and by learning to understand their concerns as legitimate, surrenders any pretense to being value free. He or she becomes partisan (Gouldner, 1968), as it should be. Once you have spent enough time behind the walls and seen the way human beings live in animal cages, and listen carefully to what prisoners say, researchers will know why they have to take a side.

\section{An Invitation to Join Us: Changing Corrections}

Unfortunately, the primary focus of correctional work has been on controlling prisoners rather than providing them with services, programs, and opportunities for personal growth. The real problem is finding ways to control the abuse of legal authority that allows the state to imprison millions of poor, minority, and young people by criminalizing common, non-violent activity and behavior (Ross, 1995/2000, 2000; Richards and Avey, 2000).

The convict perspective suggests several policy recommendations for civilizing corrections, lowering the rate of recidivism, and reducing the number 
of men and women in prison. We advocate the following: dramatic reductions in the national prison population by reducing prison sentences for prisoners; reduction of prison time for good behavior; the requirement that all prisoners have single cells or rooms; better food and clothing; vocational and family skills programs; higher education opportunities; voting rights for all prisoners and felons; voluntary drug education therapy; an end to the use of prison snitches; and the termination of the drug war. These recommendations will be further developed and debated by colleagues concerned with the humanitarian reform of criminal justice.

Indeed, there will be more research that will be conducted and essays written from a Convict Criminology perspective. We already have plans for a number of prison studies. Additionally, perhaps those who are still in the closet, ex-cons with Ph.D.s who do not want to reveal their status, ex-convict graduate students, or members of the criminology/criminal justice community, may feel empowered by this discussion. We invite you to join us.

\section{REFERENCES}

Abbott, Jack Henry. (1981). In the Belly of the Beast: Letters from Prison. New York: Random House.

Abu-Jamal, Mumia. (1995). Live from Death Row. New York: Addison-Wesley. . (2000). All Things Censored. New York: Seven Stories Press.

Arrigo, Bruce A. (1998a). "Marxist Criminology and Lacanian Psychoanalysis: Outline for a General Constitutive Theory of Crime." In Jeffrey Ian Ross (Ed.), Cutting the Edge: Current Perspectives in Radical Critical Criminology and Criminal Justice. Westport, CT: Praeger, pp. 40-62.

(1998b). Social Justice: The Maturation of Critical Theory in Law, Crime, and Deviance. Belmont, CA: Wadsworth.

Austin, James, and Irwin, John. (2001). It's about Time. Belmont, CA: Wadsworth.

Bergner, Daniel. (1998). The God of the Rodeo: The Quest for Redemption in Louisiana's Angola Prison. New York: Ballantine.

Burton-Rose, Daniel, Pens, Dan, and Wright, Paul (Eds.). (1998). The Celling of America: An Inside Look at the U.S. Prison Industry. Monroe, ME: Common Courage Press.

Chesney-Lind, Meda. (1991). "Patriarchy, Prisons, and Jails: A Critical Look at Trends in Women's Incarceration.” The Prison Journal, 63: 47-65.

Chessman, Caryl. (1954). Cell 2455 Death Row. New York: Prentice-Hall. (1955). Trial By Ordeal. New York: Prentice-Hall. . (1957). The Face of Justice. New York: Prentice-Hall.

Chevigny, Bell Gale. (2000). Doing Time: 25 Years of Prison Writing. New York: Arcade.

Churchill, Ward, and Vanderwall, J. J. (Eds.) (1992). Cages of Steel: The Politics of Imprisonment. Washington, DC: Maisonneuve Press. 
Clear, Todd R. (1994). Harm in American Penology. Albany: SUNY Press.

Cleaver, Eldridge. (1968). Soul on Ice. New York: Dell.

Clemmer, Donald. (1940/1958). The Prison Community. New York: Holt, Rinehart, and Winston.

Cohen, Stanley. (1988/1992). Against Criminology. New Brunswick: Transaction.

Conover, Ted. (2000). Newjack: Guarding Sing Sing. New York: Random House

Cromwell, Paul (Ed.).(1996). In Their Own Words: Criminals on Crime. Los Angeles: Roxbury.

Cullen, Francis T. (1995). "Assessing the Penal Harm Movement." Journal of Research in Crime and Delinquency, 32: 330-358.

Daly, Kathleen. (1994). Gender, Crime, and Punishment. New Haven: Yale University Press. Earley, Pete. (1993). Hot House: Life inside Leavenworth Prison. New York: Bantam.

Farkas, Mary A. (1992). "The Impact of the Correctional Field Setting in the Research Experience." The Journal of Crime and Justice, 15: 177-184.

Ferrell, Jeff. (1993). “The World Politics of Wall Painting.” Social Justice, 20: 188-202. . (1996). Crimes of Style. Boston: Northeastern University Press. . (1998). "Stumbling toward a Critical Criminology," in Jeffrey Ian Ross (Ed.), Cutting the Edge: Current Perspectives in Radical/Critical Criminology and Criminal Justice. Westport, CT: Praeger, pp. 63-76.

Ferrell, Jeff, and Hamm, Mark S. (Eds.). (1998). Ethnography at the Edge: Crime, Deviance, and Field Research. Boston: Northeastern University Press.

Ferrell, Jeff, and Sanders, Clinton R. (1995). Cultural Criminology. Boston: Northeastern University Press.

Fisher-Giorlando, Marianne, and Jiang, Shanhe. (2000). "Race and Disciplinary Reports: An Empirical Study of Correctional Officers." Sociological Spectrum, 20:2, 169-194.

Franklin, H. Bruce (Ed.). (1998). Prison Writing in $20^{\text {th }}$ Century America. New York: Penguin. Gaucher, Bob. (1998). "Punitive Justice and the Victim's Movement." Journal of Prisoners on Prisons, 9:2, 2-16. (1999). "Inside Looking Out: Writers in Prison." Journal of Prisoners on Prisons, $10: 1 \& 2,14-31$.

Gordon, Dianna R. (1990). The Justice Juggernaut: Fighting Street Crime, Controlling Citizens. New Brunswick: Rutgers University Press.

Gouldner, Alvin. (1968). "The Sociologist as Partisan: Sociology and the Welfare State." American Sociologist 3 : 103-116.

Hamm, Mark. (1995). The Abandoned Ones. Boston: Northeastern University Press.

Hassine, Victor. (1996). Life without Parole: Living in Prison Today. Los Angeles: Roxbury. Irwin, John. (1970). The Felon. Englewood Cliffs, NJ: Prentice-Hall. . (1980). Prisons in Turmoil. Boston: Little, Brown. . (1985). The Jail. Berkeley: University of California Press.

Irwin, John, and Cressey, Donald. (1962). “Thieves, Convicts, and Inmate Culture." Social Problems, 2: 142-155.

Jackson, George. (1970). Soledad Brother: The Prison Letters of George Jackson. New York: Coward, McCann. . (1972). Blood in My Eye. New York: Random House.

Jacobs, James. (1977). Statesville. Chicago: University of Chicago Press. Jenet, Gene. (1949a). Haute Surveillance (Death Watch). Paris: Libraire Gallimard. 
. (1949b). Journal du Voleur (A Thief's Journal). Paris: Libraire Gallimard.

Johnson, Robert. (1996). Hard Time: Understanding and Reforming the Prison. Belmont, CA: Wadsworth.

Johnson, Robert, and Toch, Hans (Eds.). (1999). Crime and Punishment: Inside Views. Los Angeles: Roxbury.

Jones, Richard S., and Schmid, Thomas (1989). "Inmates' Conception of Prison Sexual Assault." The Prison Journal, 69: 53-61.

(1993). "Ambivalent Actions: Prison Adaptation Strategies of First-Time, Short-

Term Inmates.” Journal of Contemporary Ethnography, 21:4, 439-463.

(2000). Doing Time: Prison Experience and Identity Among First Time Inmates. Stamford, CT: JAI Press.

Leder, Drew (Ed.). (1999). The Soul Knows No Bars: Inmates Reflect on Life, Death and Hope. Oxford: Rowman and Littlefield.

Lombardo, Lucien. (1989). Guards in Prison: Correctional Officers at Work. Cincinnati, $\mathrm{OH}$ : Anderson.

Lynch, Michael J. (1996). “Assessing the State of Radical Criminology.” In Peter Cordella and Larry Siegel (Eds.). Readings in Contemporary Criminological Theory, Boston: Northeastern University Press, pp. 294-304.

Martin, Dannie M. (with Peter Y. Sussman). (1995). Committing Journalism: The Prison Writings of Red Hog. New York: W.W. Norton \& Co.

May, John P. (Ed.). (2000). Building Violence: How America's Rush to Incarcerate Creates More Violence. Thousand Oaks, CA: Sage.

McCleary, Richard. (1978/1992). Dangerous Men: The Sociology of Parole. New York: Harrow and Heston.

Miller, Jerome G. (1996). Search and Destroy: African-American Males in the Criminal Justice System. New York: Cambridge University Press.

Miller, J. Mitchell, and Tewksbury, Richard. (2000). Extreme Methods: Innovative Approaches to Social Science Research. Needham, MA: Allyn \& Bacon.

Mitford, Jessica. (1973). Kind and Usual Punishment. New York: Alfred A. Knopf.

Morris, James McGrath. (1998). Jailhouse Journalism: The Fourth Estate behind Bars. New York: McFarland.

Newbold, Greg. (1982/1985). The Big Huey. Auckland, NZ: Collins. . (1987). Punishment and Politics: The Maximum Security Prison in New Zealand. Auckland, NZ: Oxford University Press. (2000). Crime In New Zealand. Palmerston North, NZ: Dunmore Press.

Owen, Barbara. (1998). In the Mix: Struggles and Survival in a Women's Prison. Albany, NY: SUNY Press.

Peak, Ken. (1985). "Correctional Research in Theory and Practice: Political and Operational Hindrances." Criminal Justice Review, 10:21-31.

Peltier, Leonard. (1999). Prison Writings: My Life Is My Sundance. New York: St. Martin's Press.

Pepinsky, Harold E., and Quinney, Richard (Eds.). (1991). Criminology as Peacemaking. Bloomington: Indiana University Press.

Quinney, Richard. (1998). "Criminology as Moral Philosophy, Criminologist as Witness." Contemporary Justice Review, 1, 347-364. 
Reiman, Jeffrey. (1995). The Rich Get Richer and the Poor Get Prison. Needham Heights, MA: Allyn \& Bacon.

Richards, Stephen C. (1990). "The Sociological Penetration of the American Gulag." Wisconsin Sociologist, 27:4: 18-28.

. (1995). The Structure of Prison Release. New York: McGraw-Hill.

. (1998). "Critical and Radical Perspectives on Community Punishment: Lesson from the Darkness." In Jeffrey Ian Ross (Ed.), Cutting the Edge: Current Perspectives in Radical/Critical Criminology and Criminal Justice. Westport, CT: Praeger, pp. 122144.

Richards, Stephen C., and Avery, Michael J. (2000). "Controlling State Crime in the United States of America: What Can We Do about the Thug State?" In Jeffrey Ian Ross (Ed.), Varieties of State Crime and its Control. Monsey, NY: Criminal Justice Press, pp. 31-57.

Richards, Stephen C., and Jones, Richard S. (1997). "Perpetual Incarceration Machine: Structural Impediments to Post-Prison Success.” Journal of Contemporary Criminal Justice, 13:1, 4-22.

Rideau, Wilbert. (1994). "Why Prisons Don't Work.” New York Times (March 21), p. 80.

Rideau, Wilbert, and Wikberg, Ron (Eds.). (1992). Rage and Survival behind Bars. NY: Times Books.

Rosenblatt, Elihu (Ed.). (1996). Criminal Injustice: Confronting the Prison Crisis. Boston: South End Press.

Ross, Jeffrey Ian (Ed.). (1995/2000). Controlling State Crime. New Brunswick, NJ: Transaction Press.

(1998). Cutting the Edge: Current Perspectives in Radical/Critical Criminology and Criminal Justice. Westport, CT: Praeger. Press.

Sutherland, Edwin H. (1937). The Professional Thief. Chicago: University of Chicago Press.

Sutherland, Edwin H., Cressey, Donald R., and Luckenbill, David F. (1992). Principles of Criminology. Dix Hills, NY: General Hall.

Sykes, Gresham M. (1956). "Men, Merchants, and Toughs: A Study of Reactions to Imprisonment." Social Problems, 4: 130-138. . (1958). The Society of Captives. Princeton: Princeton University Press.

Sykes, Gresham M., and Messinger. Sheldon L. (1960). "The Inmate Social System." In Richard Cloward et al. (Eds.), Theoretical Studies in the Social Organization of the Prison. New York: Social Science Research Council, pp. 5-19.

Taylor, Ian, Walton, Paul, and Young, Jock. (1973). The New Criminology. London: Routledge and Kegan Paul.

Taylor, Jon Marc. (1995). "The Resurrection of the Dangerous Classes." The Journal of Prisoners on Prisons, Vol. 6:2, 7-16.

Terry, Charles M. (1997). "The Function of Humor for Prison Inmates." Journal of Contemporary Criminal Justice, 13:1, 23-40.

Vold, George B., and Bernard, Thomas. (1996). Theoretical Criminology. New York: Oxford University Press.

Walens, Susann. (1997). War Stories: An Oral History of Life behind Bars. Westport, CT: Praeger.

Welch, Michael. (1996). Corrections: A Critical Approach. New York: McGraw-Hill. 
(1999). Punishment in America: Social Control and the Ironies of Imprisonment. Thousand Oaks, CA: Sage.

Wicker, Tom, (1975). A Time to Die. New York: Quadrangle.

Young, Jock, and Matthews, Roger. (1992). Rethinking Criminology: The Realist Debate. London: Sage.

Stephen C. Richards is Associate Professor of Sociology and Criminology at Northern Kentucky University. He is an ex-convict, having served time in federal penitentiaries, correctional institutions, and camps. His published work has been on tattoos, prison conditions, prison release, community punishments, and state crime. He is a Soros Senior Justice Fellow and serves on the American Society of Criminology National Policy Committee. He can be contacted at richards@nku.edu.

Jeffrey Ian Ross is Assistant Professor in the Division of Criminology, Criminal Justice and Social Policy at the University of Baltimore. He has conducted research, written and lectured on national security, political violence, political crime, violent crime, corrections, and policing. His work has appeared in many academic journals and books. He can be reached at jross@ubmail.ubalt.edu.

Stephen Richards and Jeffrey Ian Ross have co-authored Behind Bars: Surviving Prison, 2002, and have co-edited Convict Criminology, 2003.

The Journal of Prisoners on Prisons wishes to thank Wadsworth Publishing for permission to reproduce this article, which first appears in Convict Criminology. 